\title{
Browntop seed production: Past, present and future
}

B.R. GUY', W.J. ARCHIE ${ }^{2}$ and J.S. ROWARTH ${ }^{2}$ 'Challenge Seeds, Kirnihia Research Centre, P. O. Box 939, Christchurch ${ }^{2} D S I R$ Grasslands, Private Bag, Christchurch

\begin{abstract}
A survey of 'Grassland Egmont' browntop (Agrostis capillaris syn. A. tenuis) seed yields (1987-1989 incl.) showed a range in production from 0 to over $400 \mathrm{~kg} / \mathrm{ha}$, with a relatively low average yield (107-147 $\mathrm{kg} / \mathrm{ha})$. In order to elucidate the problems associated with growing Egmont for seed, crops on 23 farms were monitored during the 1989/90 growing season. Trends on yield data were then analysed according to precipitation (rainfall or irrigation) and soil type. Precipitation was found to be the major factor in limiting seed yields. With this information, refinements were developed to present management systems including fertiliser application, weed control, irrigation and harvest and post-harvest management.
\end{abstract}

Keywords browntop, seed production, irrigation, 'Grasslands Egmont'

\section{Introduction}

'Grasslands Egmont' (A grostis capillaris syn. A. tenuis) is a dark green amenity browntop suitable for home lawns, parks, golf greens and other areas which do not receive severe wear (Rumball \& Robinson 1982). The overseas market potential of Egmont is such that seed supply has not kept up with seed demand.

Although some work on browntop has been done overseas (Chilcote \& Youngberg 1974; Canode 1980; Youngberg 1980; Nordestgaard 1983), results applicable to New Zealand (because of differences in climate and regulations on burning and sprays) are limited. Present recommendations for management are based on general grass seed crop principles and on results from trials done at Lincoln (Brown \& Archie 1986).

The first commercial crops of Egmont browntop were harvested in Canterbury in 1985. Yields were $371 \mathrm{~kg} / \mathrm{ha}$ in the first year, but only $176 \mathrm{~kg} / \mathrm{ha}$ in the second year.

A survey of seed yields (1987-1989 incl.; Table 1) showed a wide range in production from 0 (where crops were too poor to harvest) to over $400 \mathrm{~kg} / \mathrm{ha}$, with a relatively low average yield (107-147 kg/ha). In order to elucidate the problems associated with growing Egmont for seed, crops were monitored during the 1989190 growing season as part of the Emerging Technologies Programme between Challenge Seeds and DSIR Grasslands.

Table I Egmont browntop seed yields (kg/ha).

\begin{tabular}{ccc}
\hline Year & Average & Range \\
\hline $\mathbf{1 9 8 6 / 8 7}$ & 107 & $21-138$ \\
$\mathbf{1 9 8 7 / 8 8}$ & 147 & $14-327$ \\
$\mathbf{1 9 8 8 / 8 9}$ & 118 & $\mathbf{4 - 4 1 0}$ \\
$\mathbf{1 9 8 9 / 9 0}$ & 262 & $15-533$ \\
\hline
\end{tabular}

\section{Method}

Egmont seed crops on 23 farms in mid and south Canterbury were visited at 6-weekly intervals during the 1989/90 growing season. Trends on seed yield data were then analysed according to precipitation (rainfall or irrigation) and soil type. Information on irrigation was obtained from farmers; rainfall and soil type was obtained from NZ Soil Bureau Bulletin 14. Crops were classed as dry $(0-635 \mathrm{~mm}$; visible signs of moisture stress -during--growing season), moist (635-760 mm; no visible signs of moisture stress) or irrigated.

\section{Results}

Seed yield increased with increasing amounts of precipitation (Figure 1), despite large variability in seed yield between farms owing to differences in soil type and on-farm management.

Seed yield increased with increasing clay content (and consequent water holding capacity; Figure 2). Exceptions to this trend (apparent on some stony soils) were a result of regular irrigation from October until full flowering.

\section{Conclusions}

The average browntop seed yield for the 1989190 season was almost $80 \%$ higher than the previous best average and the top grower produced 30\% more than in the previous season. The main limiting factor apparent in this survey was water. Highest yields came from heavy soils with a high water holding capacity. Good yields were obtained from stony soils on/y where irrigation had been frequent. 


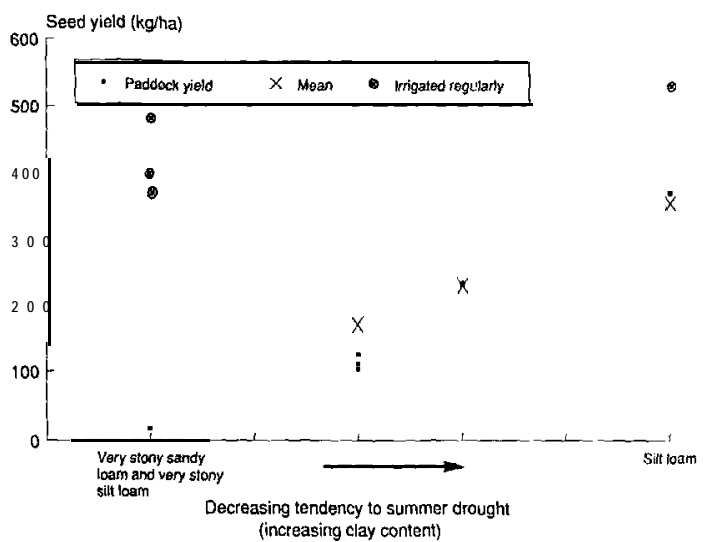

Figure 1 Effect of increasing moisture on machine-dressed seed yield ( $\mathrm{kg} / \mathrm{ha}$ ) of 'Grasslands Egmont' in the 1989/90 season.

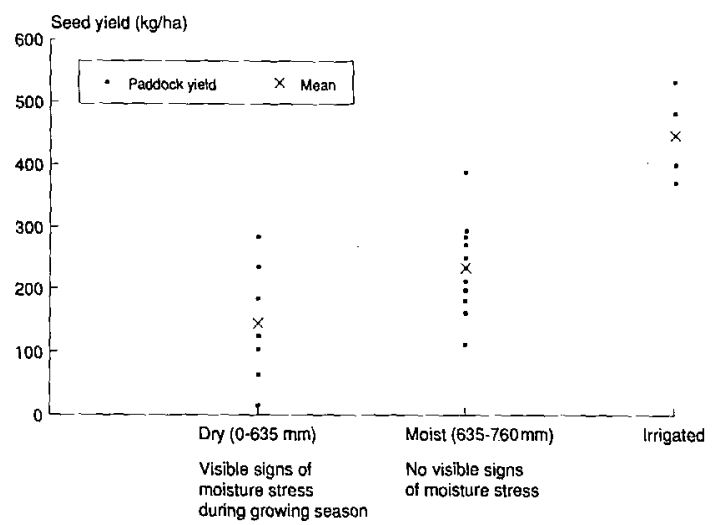

Figure 2 Effect of increasing clay content (and consequent moisture holding capacity) on machinedressed seed yield of 'Grasslands Egmont' in the 1989/90 season.

Research is necessary to define critical times in the development of browntop seed heads when moisture stress reduces seed yield. Response to increasing rates of nitrogen also requires investigation; results from a preliminary trial (Brown \& Archie 1986) were inconclusive. Observation of crops throughout the 1989/90 growing season enabled many comparisons of crop management to be made. These observations, coupled with results from the yield survey, enabled refinements to the present management systems for non-rhizomatic browntop seed crops to be developed. These refinements are applicable for Canterbury; at present, certified browntop is not grown commercially in any other area of New Zealand.

\section{Management guidelines}

By following the guidelines outlined, it should be possible to maximise seed production within the constraints of precipitation and soil type. It follows that paddocks for seed crops should be selected in areas of good precipitation and water holding capacity (i.e., sufficient to prevent moisture stress).

\section{sowing}

Browntop should be surface-sown or shallow-drilled in moist soil in early autumn (mid-February to midMarch) at 2-3 $\mathrm{kg} / \mathrm{ha}$, preferably with an insecticide. Nitrogen fertiliser used at sowing (up to 30 units of $\mathbf{N}$, particularly if sowing is late) assists the production of strong plants prior to winter. The crop should be irrigated if dry to assist seedling growth. Any likely nutrient deficiencies in the soil (e.g., phosphorus) should be corrected at this stage.

\section{Establishment}

The crop should not be grazed. If broad-leaf weeds are apparent, herbicides should be used in early winter to control winter active weeds (e.g., *chickweed). A range of broad-leaf herbicides is available (although very few have registration for seed crops). If spraying before tillering, chemicals containing dicamba (dimethyl amine salt) should not be used.

\section{Spring}

Herbicide should be used if weeds are competing vigorously. Nitrogen should be used if 'springyellows' are apparent, i.e., if plants are under stress, and $\mathrm{N}$ should be applied around head elongation (mid-late October to early November; Brown \& Archie 1986). Amounts of $\mathrm{N}$ used should be increased with stand age. The survey showed good responses to 100 units of $\mathrm{N}$ (applied as $2 \times \mathbf{5 0}$ units, 2-3 weeks apart) in first year crops and 120 units in older crop.

The crop should be irrigated throughout the spring and summer to avoid any moisture stress. Amount necessary will depend on rainfall and soil type.

\section{Harvesting}

The crop should be mown with a knife (i.e., sickle bar or busatis), allowed to dry, and then picked up on a hot day (when the seed is threshed easily).

\section{Post-harvest}

Straw can be raked and baled, or spread out and burnt. It should not be burnt in the windrow as the excessive heat generated destroys plants and results in weed ingress. Post-harvest management should aim at preventing thatch build-up (i.e., by grazing hard or cutting low) and letting light into the base of the sward to promote new tillering. Stock should be removed by the end of June, and the crop closed for seed.

If soil fertility is low, a compound fertiliser should be applied in autumn. Soil tests can be done every 3-4 years to give a general indication of fertility and modifications made accordingly. Nitrogen and water may be required post-harvest to produce healthy, vigorous plants prior to winter. 


\section{Summary}

For high yields of seed, browntop should be regarded and treated as a crop, not as a hardy hill country grass.

\section{REFERENCES}

Brown, K.R.; Archie, W.J. 1986. Effect of nitrogen application on seed production of 'Grasslands Egrnont' and 'Grasslands Sefton' browntops (Agrostis capillaris). $N Z$ journal of experimental agriculture 14 : 257-260.

Canode, C.L. 1980. Grass seed production in the intermountain Pacific North-West, USA. pp. 189-201. In Hebblethwaite, P.D. (ed.), Seed production. London, Butterworths.

Chilcote, D.O.; Youngberg, H.W. 1974. Field burning techniques and alternatives. pp. 202-213. In Hebblethwaite, P.D. (ed.), Seed production. London, Butterworths.

Nordestgaard, A. 1983. Trials on time of nitrogen application in spring to various grasses grown for seed production. Proceedings of the 14th International Grassland Congress: 25 1.253.

Rumball, W.; Robinson, G.S. 1982. 'Grasslands Egmont' amenity browntop (Agrostis capillaris L. syn. A. tenuis Sibth.). NZ journal of experimental agriculture 10: 175-177.

Youngberg, H.W. 1980. Techniques of seed production in Oregon. pp. 202-213. In Hebblethwaite, P.D. (ed.), Seed production. London, Butterworths. 